\title{
Vivências depressivas e relações de trabalho: uma análise sob a ótica da Psicodinâmica do Trabalho e da Sociologia Clínica
}

\author{
Depressive experiences and working relations: an analysis from the perspective of the \\ Psychodynamics of Work and Clinical Sociology
}

Antonio Roziano Ponte Linhares ${ }^{1}$

Marcus Vinicius Soares Siqueira ${ }^{2}$

\begin{abstract}
Resumo
O trabalho bancário se encontra envolto pelo ideário financeiro, subestima o social e se revela máquina de vulnerabilizar e invalidar os bancários, que apresentam índices crescentes de depressão. Verificou-se, assim, a necessidade de identificar vivências depressivas ocorridas no ambiente bancário, seus efeitos sobre as relações de trabalho e subjetividade dos trabalhadores, à luz da abordagem qualitativa, da Sociologia Clínica e Psicodinâmica do Trabalho. A fala dos bancários nos revelou a precarização de suas condições de trabalho, que lhes impõe a ética do individualismo; o medo; a solidão; a abdicação dos desejos; o sequestro da fala, da inteligência e o advento da depressão, sinalizadora de perigo, o que exige a revisão de práticas de gestão e relações instituídas entre bancos e bancários, de forma a viabilizar a reconquista da consciência e da autonomia, além do empoderamento da governança e, por conseguinte, o resgate da solidariedade, da confiança, da renovação dos desejos e prazer no trabalho.
\end{abstract}

Palavras-chaves: Trabalho. Bancário. Gestão. Saúde. Depressão.

\begin{abstract}
The job in the bank is wrapped by financial ideas, underestimates the social and reveals itself as a weaken machine which invalidates the bank clerks, who show increasing rates of depression. There was, thus, a need to identify the depressive experiences in the banking environment, its effects overwork relations and subjectivity of workers in the light of the qualitative approach, from Clinical Sociology and Psychodynamic of Work. The speech of the bank clerks revealed the precariousness of working conditions, which impose the ethics of individualism, fear and loneliness, abdication of desires, kidnapping of speech, intelligence and depression: a danger sign that demands a review of management practices and established relationships between banks and bank clerks, in order to facilitate the regaining of consciousness and autonomy, besides the empowerment of governance, and therefore, the rescue of solidarity, trust, renewal of desires and pleasure at work.
\end{abstract}

Keywords: Work. Bank Clerk Management. Health. Depression.

Artigo submetido em 17 de agosto de 2013 e aceito para publicação em 01 de julho de 2014.

DOI: http://dx.doi.org/10.1590/1679-395110385

${ }^{1}$ Doutor em Administração pela Universidade de Brasília; Professor da Universidade Estácio de Sá. Endereço: Rua Eunice Weaver, 210 - Casa 29 - Sapiranga, CEP 60833-365, Fortaleza - CE, Brasil. E-mail: linnhares@ig.com.br

${ }^{2}$ Pós Doutor em Sociologia Clínica e Psicologia (Laboratoire de Changement Social - Paris VII e Université Catholique de Louvain); Doutor em Administração de Empresas pela EAESP-FGV-SP; Professor da pós-graduação em Administração da Universidade de Brasília - UnB. Endereço: SQN 212 - Apartamento 414 - Asa Norte, CEP 70864-000, Brasília - DF, Brasil. E-mail: marc-vs@uol.com.br 


\section{Introdução}

Com o advento do capitalismo informacional, modelo de desenvolvimento surgido no último quartel do século XX que se ancora na ação da tecnologia e do conhecimento como fonte de produtividade (CASTELLS, 1999), impõe-se aos homens o fluxo rápido do conhecimento e da informação que, sem fronteiras limitadoras de seu trânsito entre comunidades e países, instituiu a mudança como única certeza numa sociedade que exige dos trabalhadores a necessidade de adaptações contínuas frente ao conjunto de transformações do mundo do trabalho.

Entre referidas transformações se destaca o surgimento da sociedade de serviços (setor terciário); da era da informatização; da flexibilização da jornada e do local de trabalho; da instabilidade no emprego; da maior demanda por profissionais mais qualificados; da heterogeneização do trabalho;do agravamento das condições de saúde, bem como da expansão do trabalho parcial, temporário, precário, subcontratado e terceirizado (ANTUNES, 2011).

O trabalho bancário também vivencia este cenário de transformações, tendo sido impactado mais recentemente pela revolução tecnológica(Banco 24 horas; autoatendimento; internet; captura e transferência eletrônica de dados) e por demandas do ideário neoliberal (foco exclusivo nos resultados financeiros; terceirização das atividades bancárias; legalização do contrato temporário de trabalho; e redesenho do perfil dos bancários, agora vendedores de produtos e serviços). Referidas transformações demandam contínuas adaptações e ações de qualificação multireferenciadas (administração, marketing estratégia, vendas, finanças, etc.), elementos necessários não somente para o encarreiramento dos bancários, mas também para a manutenção de seus empregos, cargos e comissões (JINKINGS, 1995).

Assim, diante de um cenário que, segundo Jinkings (1995),impõe aos bancários a cultura da urgência e da eficácia (pressões para o cumprimento de metas),o medo e insegurança (receio da perda de emprego e reduções salariais), além da competição entre pares e a luta por lugares e visibilidade diante das demandas insatisfeitas de reconhecimento (DEJOURS, 1994), disseminam-se entre os bancários "sentimentos de desvalorização de si, a ruptura das redes de solidariedade, a perda dos elementos constitutivos da identidade profissional, a culpabilidade, a vergonha, o fechamento sobre si e a ruptura da comunidade de trabalho" (GAULEJAC, 2007, p. 201). Confirma-se, assim, a previsão de Castel (2010), para quem a nova organização do trabalho se constituiria fator permanente de insegurança social, máquina de vulnerabilizar e até invalidar os trabalhadores.

Desta forma, imersos num cenário de precarização do trabalho, os bancários se deparam com uma realidade de sofrimento e desamparo, onde a civilização do progresso material, fundada pela ideologia do progresso, associada à ciência e à técnica "não pôde realizar a suposta felicidade ampla, geral e irrestrita, conforme prometera em suas origens heroicas"(BIRMAN, 2000, p. 40) e, ao contrário, impôs o terrorismo do pensamento único, do conformismo generalizado (MARCUSE, 1967), da ascensão da insignificância e da fecundação do homem utensílio, facilmente descartado pelas organizações quando da não consecução de seus objetivos (ENRIQUEZ, 2006).

O quadro de sofrimento e desamparo vivenciado pelos bancários foi fortemente impactado quando da implementação dos processos de reestruturações produtivas conduzidos pelos bancos no início da década de 90 do século passado, os quais impuseram aos trabalhadores o nomadismo involuntário, fenômeno que, segundo Grisci, Cigerza, Hofmeister et al. (2006), contribuiu para a instabilidade dos vínculos de amizade, das relações pessoais e familiares, além da fragilização da subjetividade dos trabalhadores, fatores que favoreceram o surgimento de um quadro crescente de patologização no universo laboral.

Referido quadro se caracterizou pela emergência de um conjunto de aflições psíquicas, entre as quais se destaca a depressão (GRISCI, 2003), conforme também identificado pelas pesquisas realizadas por Ferreira e Seidl (2009), para quem o mal-estar no trabalho bancário não é caracterizado por meros desconfortos, 
constituem-se efetivamente de fatores geradores de sofrimento psíquico e adoecimento, inclusive a depressão, que tem entre os bancários suas vítimas mais frequentes (TEIXEIRA, 2007).

Dados divulgados pelo Ministério da Previdência Social (2012)reforçam referida percepção ao nos revelarem que os transtornos mentais e de comportamento decorrentes do trabalho tiveram desde 2007 um incremento de 50,81\%, ocupando, pelo menos desde 2009, o terceiro lugar em número de auxílios-doença acidentários concedidos. Os mesmos dados nos revelam, ainda que, não obstante uma redução do número de trabalhadores afastados do trabalho por depressão, na ordem de 13,96\% (posição em dezembro de 2012), quando analisamos o universo bancário nos deparamos com um movimento contrário:incremento anual de um por cento dos profissionais deste segmento entre as vítimas de depressão, conforme dados constantes da tabela a seguir:

Tabela 1

\section{Evolução da depressão entre bancários}

\begin{tabular}{|l|l|l|l|l|}
\hline Número de afastamentos/ ano & 2009 & 2010 & 2011 & 2012 \\
\hline Total geral dos afastamentos & 13478 & 12150 & 12337 & 11597 \\
\hline Total de afastamentos dos bancos & 780 & 811 & 976 & 1073 \\
\hline Evolução dos afastamentos nas atividades bancárias & $6 \%$ & $7 \%$ & $8 \%$ & $9 \%$ \\
\hline
\end{tabular}

Fonte: Ministério da Previdência e Assistência Social (2012)

Os dados anteriores se mostram ainda mais relevantes quando consideramos que muitas vezes os trabalhadores adoecem em função de esforços oriundos de suas atividades profissionais e pensam tratar-se de uma doença comum. Assim, ao invés de requererem a comunicação de acidente de trabalho, para dar entrada no benefício auxílio-acidentário, acabam requerendo o auxílio- doença previdenciário, o qual não vincula o adoecimento ao trabalho, fato este que suscita a incidência de depressão vinculada ao trabalho num número ainda maior de trabalhadores.

A preocupação com a questão da depressão entre os bancários torna-se ainda mais relevante diante dos dados fornecidos pelo estudo de Santos (2010, p. 09), que abordou o suicídio no setor bancário e segundo o qual "em média, entre 1993 e 2005, pelo menos um bancário cometeu suicídio a cada 20 dias, estimando-se uma ocorrência diária de tentativa (não consumada) durante todo o período". Considerando-se, ainda, que muitos casos de suicídios ou tentativas não são notificados, o problema revela-se, ainda maior, fenômeno este que também se dá com a depressão, já que o depressivo, por receio do preconceito, não raramente recolhe sua dor à solidão e, quando não, recorre muitas vezes à automedicação.

Assim, diante deste cenário, faz-se necessário mergulhar no universo laboral dos bancários com o objetivo de identificar vivências depressivas no ambiente bancário, bem como seus impactos nas relações de trabalho e na subjetividade dos trabalhadores, o que contribuirá para um diagnóstico mais preciso da realidade bancária; maior conscientização de bancários e banqueiros sobre o conjunto de práticas que contribuem para o recrudescimento da depressão neste segmento de trabalhadores e, por conseguinte, para um repensar das práticas de gestão instituídas no ambiente laboral, de forma a viabilizar-se não somente o resultado financeiro esperado pelas organizações, mas também o bem-estar no trabalho. 


\section{O itinerário da depressão no mundo do trabalho}

O desconforto dos trabalhadores no mundo das organizações parece acentuar-se diante das demandas da Ideologia do Progresso e da Racionalidade Instrumental que, reféns da lógica financeira, da cultura da urgência e do alto desempenho, recorreram ao gerencialismo como ferramenta amenizadora das angústias organizacionais (demandas por eficácia e produtividade). Referida ferramenta, segundo Gaulejac (2007), caracteriza-se pela dominação dos critérios econômicos e quantitativos e pela conversão das atividades humanas em indicadores de desempenho, além da transformação dos homens em utensílios organizacionais (ENRIQUEZ, 2006).

Surge, desta forma, uma sociedade sob pressão, mergulhada na cultura do medo, da insegurança, do estresse e da tensão obsessiva do sempre melhor, o que fomentou o espírito de competição, a luta por lugares e a busca do sucesso e do resultado a qualquer custo (GAULEJAC, 2007), como forma de assegurar-se a visibilidade necessária à obtenção do reconhecimento organizacional, condição para a sobrevivência dos trabalhadores dentro das organizações(DEJOURS, 1994).

Vivenciamos, portanto, segundo Dejours (1994), um momento de crise da solidariedade, o desengajamento pessoal e a destruição das relações de confiança, ou seja, o apogeu do individualismo triunfante sobre os valores vacilantes das consciências coletivas. Por isso, ainda segundo Dejours (2004),o individualismo seria uma derrota e não um ideal, já que seria responsável pela banalização de comportamentos desleais que fomentam a busca do ostracismo do outro diante do temor de perder para ele o reconhecimento da organização.

O empoderamento do individualismo se dá, portanto, diante de um cenário onde as pessoas são tidas como variável de ajustamento e o conjunto de trabalhadores é seduzido por mecanismos gestionários (adesão voluntária em vez de sanção disciplinar; mobilização em vez de obrigatoriedade; incitação em vez de imposição; gratificação em vez de punição e responsabilidade em vez de vigilância) que lhes sequestram a própria subjetividade (GAULEJAC, 2007) e, por conseguinte, o benefício da dúvida e do contraditório,fonte de sua criatividade e inteligência (DEJOURS, 1994), as quais só são bem-vindas no mundo organizacional quando atuam em prol da eficácia das organizações.

Os trabalhadores renderam-se ainda ao sentimento de culpa e à vergonha (DEJOURS, 1994; GAULEJAC, 2006) quando se depararam com o tabu do fracasso, temor de não consecução dos resultados esperados pelas organizações (SENNET, 2006). Tais sentimentos, não obstante constituir-se mecanismo de compensação psicológica (fonte de expiação dos débitos imaginários dos trabalhadores com as organizações), também contribuíram para o mergulho dos trabalhadores num quadro de "sofrimento psíquico e problemas relacionais que são efeitos dos modelos de gerenciamento" adotados pelo gerencialismo (GAULEJAC, 2007, p. 225).

Deparam-se, assim, organizações e trabalhadores com o adoecimento da gestão, fato esse corroborado por Abrahão e Torres (2004), quando nos afirmam que os trabalhadores imersos num cenário marcado pela sobrecarga de trabalho e pelo uso do constrangimento, intimidação e medo como ferramentas gerenciais, rendem-se à necessidade de transgredir para atingir os objetivos das organizações de trabalho, mesmo que para isso tenham que agir de acordo com preceitos que consideram eticamente condenáveis (SZNELWAR, UCHIDA e LANCMAN, 2011), o que os conduz inexoravelmente ao sofrimento ético (MENDES, 2010b).

Desta forma, os trabalhadores se defrontam com um quadro cada vez mais perverso de desamparo e sofrimento (DEJOURS, 2007; GAULEJAC, 2011), caracterizado pela emergência do estresse, intensificação das tensões e cargas psíquicas,banalização do logro e injustiça social, aumento do desemprego, enfraquecimento da proteção social, ruptura entre empresa, dirigentes e trabalhadores, além da presença de problemas psicossomáticos, fatores que culminam com o sentimento de insatisfação no trabalho, bem como com o agravamento das condições de saúde diante da exposição dos trabalhadores a tantos fatores psicossociais adversos (BARRETO e SILVA, 2012). 
Todos esses fatores contribuem, segundo Gaulejac (2011) e Dejours e Mello Neto (2004),para a fecundação de patologias mentais, entre elas a depressão, fato também apontado por Sznelwar, Uchida e Lancman (2011) quando afirmam que não seria exagero imputar aos atuais modos de produção do trabalho (cultura da urgência, pressões por eficácia, ameaças veladas, espírito de competição, ruína da solidariedade, etc.) graves problemas de saúde mental, como síndromes de pânico e depressão.

A preocupação com a depressão no universo laboral ganha ainda maior relevância porque, segundo Dejours e Mello Neto (2012), contrariamente à percepção de alguns analistas, ela poderia inclusive levar ao suicídio e, quando na ausência de quaisquer antecedentes psicopatológicos, referida patologia parece estar estreitamente ligada à degradação da situação do trabalho. Referida hipótese ganha força diante da ocorrência de suicídios cometidos por trabalhadores, cujo sofrimento decorre de sua relação com o trabalho, sem que tenha se apresentado entre eles qualquer transtorno psicopatológico anteriormente, a exemplo dos casos de suicídios ocorridos na France Telecom, onde,desde 2008, já foram24 suicídios em 18 meses e na Renault francesa, onde, desde 2007,diversos funcionários se suicidaram por pressões no ambiente de trabalho (MERLO, 2009; PAZ, 2009).

Segundo Peres (2010, p. 28), a depressão teria duas linhas interpretativas: a corrente psiquiátrica e a corrente psicanalista. Segundo a corrente psiquiátrica,as síndromes depressivas têm como elementos mais salientes o humor triste e o desânimo, visão essa também compartilhada por Del Porto (1999), para quem os episódios depressivos podem ser classificados como leves e moderados, quando presentes ou ausentes sintomas somáticos e também como graves, diante da presença ou ausência de sintomas psicóticos.

Assim, à luz da perspectiva psiquiátrica, negligenciam-se a ideia de conflito, a importância do inconsciente, da história, singularidade e personalidade dos pacientes (PERES, 2010), privilegiando-se a linguagem dos sintomas, que,segundo Del Porto (1999),são segmentados em três tipos: sintomas psíquicos (humor depressivo; redução da capacidade de experimentar prazer na maior parte das atividades antes consideradas agradáveis; fadiga ou sensação de perda de energia; diminuição da capacidade de pensar, de se concentrar ou de tomar decisões); sintomas fisiológicos (alterações de sono, de apetite e redução do interesse sexual) e sintomas comportamentais (retraimento social; crises de choro; comportamentos suicidas; retardo psicomotor e lentificação generalizada ou agitação psicomotora).

Numa tentativa de resgatar a importância dos aspectos psicológicos, a perspectiva psicanalista propõe uma nova maneira de pensar o sofrimento psíquico, ao enfatizar a relevância do inconsciente e dos conflitos entre as possibilidades efetivas de realização de um indivíduo diante dos imperativos de um ideal de ego cada vez mais exigente (PERES, 2010), fato este ratificado por Gaulejac (2007), quando afirma que passamos de um sistema fundado sobre a solicitação do Superego (autoridade, obediência e culpabilidade) para um sistema fundado sobre a solicitação do Ideal de Ego (exigência da excelência, ideal de onipotência, medo de fracassar, busca da satisfação narcísica).

Peres (2010) caminha na mesma direção de Freud (2011) quando afirma que a depressão seria uma paralisia afetiva, motora ou intelectual; um sentimento de morte estando vivo; uma fraqueza do ser e um desencanto absoluto, onde o passado é insuportável, o presente uma tortura e a falta de esperança acompanha o sentimento de impossibilidade de um futuro. Desta forma, a depressão se revela uma tendência hostil em relação ao mundo, fonte redutora da capacidade de amar, o que contribui para que "o deprimido carregue uma profunda inibição e o sentimento de ser incapaz de enfrentar a vida e a luta pela existência" (PERES, 2010, p. 55).

Segundo Peres (2010),isto se daria porque, desconhecendo as causas desses sentimentos, o depressivo elabora sobre si um diagnóstico construído sob a égide da menos-valia, rendendo-se, por isso, ao sentimento de insuficiência narcísica diante de um superego cada vez mais rigoroso e cruel (KEHL, 2009) e, por consequência, também ao sentimento de culpa (GAULEJAC, 2007), filho da infidelidade ao desejo e da desistência do eu diante da assunção de uma personalidade emprestada (ENRIQUEZ, 1997 e PAGĖS, BONETTI, DE GAULEJA et al., 2006). 
Referida personalidade impõe aos trabalhadores o conformismo (rendição ao espelho do universo),a abdicação de sua singularidade, o isolamento do meio social a que o indivíduo pertence (GAULEJAC, 2007) e a morte da vergonha, que, ainda segundo Gaulejac (2006),seria a última trincheira de afirmação do sujeito, fonte mantenedora da autoestima e dos laços que ameaçam romper com a realidade.A rendição ao isolamento contribui ainda mais para a inércia das pulsões (represamento da energia dos depressivos) e para o empoderamento da depressão, tendo em vista que:

ao isolar-se do meio social a que pertence, o depressivo fica excluído da corrente de transmissão da memória coletiva. O encolhimento da memória contribui para o isolamento espiritual do depressivo na medida em que apaga os rastros que poderiam orientá-lo na direção do pertencimento a uma comunidade (KEHL, 2009, p. 236).

O isolamento do meio social dar-se-ia em função do receio e da ameaça do outro, o que é combatido por Fédida (2009) quando defende que, para compreensão de si mesmo, é preciso ser dois, em contraposição à tendência autocrática dos deprimidos, que querem curar-se sozinhos, sem depender de ninguém, tornando-se insensíveis e matando em si a necessidade de estar com alguém.

Ainda segundo Fédida (2009), referido comportamento potencializaria o advento da depressão, doença humana que afeta o exercício da comunicação com os outros, comprometendo-se, assim, a comunicação intersubjetiva e desencadeando um extraordinário empobrecimento da subjetividade, além da pauperização da vida psíquica diante do congelamento da fala pela depressão.

A assunção da depressão seria favorecida, segundo Kehl (2009), em função do desprestígio social da tristeza dos depressivos, bem como da banalização de sua solidão e sofrimento pela ética do individualismo (GAULEJAC, 2007), ética marcada pelo fatalismo ou conformismo, mecanismo mental que se sustenta pela identificação afetiva com os vencedores (KEHL, 2009). A identificação com os vencedores, segundo Pagès, Bonetti, De Gauleja et al. (2006), conduz os indivíduos à abdicação de seu "eu", que se rende ao ideário e demandas organizacionais e ao status quo, mesmo que em detrimento de suas próprias convicções. Nega-se assim, aos trabalhadores, a fala, o benefício da dúvida e do contraditório e, por conseguinte, o exercício da criatividade e de sua própria inteligência, conforme propugnado por Dejours (2004) e Castoriadis (2006).

Referidos elementos também contribuiriam para o advento da depressão já que,segundo Fédida (2009, p. 183),essa se "fundamenta no declínio do sujeito interior inibido e impotente", sujeito este fruto de uma sociedade que não se baseia mais na subjetividade, mas que se apoia no espírito do empreendedorismo, da iniciativa, da competição, do individualismo e da busca do sucesso na carreira a qualquer custo, elemento que se apresenta destemidamente como elo entre indivíduos e organizações e, por conseguinte, veículo de alienação dos trabalhadores (PAGÈS, BONETTI, DE GAULEJA et al., 2006).

Kehl (2009) e Birman (2000) acrescentam ainda que ao lado do sequestro da subjetividade se encontra a ausência essencial do desejo, elementos estes caracterizadores da depressão, visão também compartilhada por Coser (2003),quando afirma que a depressão se constitui resultado de um despovoamento simbólico, um desinvestimento do mundo exterior, ponto zero do desejo, elemento sem o qual a percepção do mundo fica desprovida de intencionalidade própria. Ratifica-se assim também a visão de Siqueira (2007),quando afirma que a depressão se instala justamente quando o sujeito abre mão de seu desejo.

Fédida (2009) também defende esta visão e acrescenta que a depressão se constitui em uma espécie de desumanização, doença do humano caracterizada pela abolição das emoções, desejos e sentimentos. Seria uma espécie de sono de hibernação, companheira de sentimentos de inferioridade e humor triste, elementos estes que anulam o gosto de viver e fazem com que o depressivo enxergue no espelho uma alma abatida, uma ferida que sangra e um buraco na sua esfera psíquica que lhes impõem o enfraquecimento do sentimento de si e a violência do vazio, usurpação e esvaziamento do eu (ego).

Isto ocorreria, segundo Coser (2003, p. 156),porque "o deprimido conserva a ilusão de que poderia alcançar a felicidade renunciando ao desejo", o que ocorre em função da identificação narcísica dos indivíduos com o 
seu objeto de amor. Assim, diante de tamanha identificação, a angústia de sua perda constituir-se-ia na própria angústia do eu que teme não sobreviver diante do desaparecimento do objeto, por isso, o eu ameaçado devora o desejo, "meio imaginário do qual se serve o eu-prazer na esperança de negar o objeto enquanto tal, como existindo separadamente dele" (FÉDIDA, 1999, p. 62).Assim, ainda segundo Fédida (1999, p. 61), "a morte do objeto desejado eliminaria a tristeza de sua não obtenção, expurgaria da alma o sofrer de sua não conquista, fazendo germinar a esperança da felicidade".

A depressão seria, ainda, um sintoma social, sinalizador de mal-estar na civilização, uma tentativa, ainda que malsucedida de cura, já que aquele que se abate e se deprime ao desistir e trair seu desejo em nome da adesão ao outro indica que de alguma forma a identificação afetiva com a alienação falhou (KEHL, 2009). Assim, "a depressão não seria apenas um estado da alma, mas uma culpa moral pela traição do desejo do sujeito, pela sua rendição ao desejo do outro" (KEHL, 2009, p. 194), o que reforça as preocupações de Enriquez (1997), Gaulejac (2007) e Pagès, Bonetti, De Gauleja et al. (2006) acerca do risco do sequestro da subjetividade dos indivíduos e da abdicação de sua personalidade em prol das organizações.

Desta forma, a depressão também atuaria como uma ferramenta protetora que não deve ser subestimada, já que, segundo Fédida (2009), seria possível, em certa medida, atribuir ao estado deprimido uma função reguladora das mudanças, como se fosse preciso ter a ousadia de levantar a hipótese segundo a qual não se deveriam exigir curas rápidas demais, visto que isto submeteria os indivíduos a falsas adaptações, além de também impedir a produção de conhecimento pela depressão, uma vez que, segundo Kehl (2009, p. 88), "é possível que os depressivos sejam os atuais detentores de um saber a respeito das condições contemporâneas do mal-estar".

Entre referidas condições, a ausência do reconhecimento se revela como um dos elementos constituintes da depressão, já que, para Kehl (2009),a depressão seria o nome contemporâneo para o sofrimento decorrente da perda do lugar dos sujeitos junto à versão imaginária do outro. Segundo Birman (2000, p. 28), isso se dá porque "nos dias atuais o olhar do outro no campo social e mediático passa a ocupar uma posição estratégica na economia psíquica", passando o reconhecimento a constituir-se determinante do bem-estar do trabalho, daí por que, quando ignorado, pode levar o homem à depressão, conforme nos afirma Enriquez (apud ARAÚJO, 2001, p. 58) na citação a seguir:

o homem sem trabalho ou não reconhecido em seu trabalho, ou ainda não encontrando nenhum interesse em seu trabalho está próximo da depressão e comumente chega a este ponto de ruptura. Pois, o trabalho em nossa sociedade é o modo privilegiado de fazer uma obra (por menor que seja), de existir, de ter ou pensar ter uma identidade. O trabalho é, atualmente, o melhor método para vencer a loucura.

A relevância do reconhecimento na economia psíquica dos trabalhadores também é reforçada por Dejours (2004, p. 32) para quem "é a partir do olhar dos outros que nos constituímos como sujeitos". Por isso, segundo Rouchy (apud Araújo, 2001, p. 134), "uma falha ou uma ambiguidade do olhar do outro seria fonte de carências e de perturbações na constituição da identidade e do laço social", o que, segundo Gaulejac (2007, p. 198), se daria porque o reconhecimento se constitui exigência indispensável do ser e "ao perder o reconhecimento da empresa muitos trabalhadores perdem sua base narcísica", sua autoestima, seu sentido do trabalho, quebrando-se, portanto, o contrato narcísico, segundo o qual o "indivíduo espera da empresa que ela favoreça sua realização, enquanto ela espera dele sua adesão incondicional” (GAULEJAC, 2007, p. 229).

Revela-se, assim, o reconhecimento como processo dinâmico mediador e constituinte da identidade do trabalhador, elo entre trabalho e identidade, prazer e sofrimento (DEJOURS, 2004; BOUYER, 2010) além de também guardar uma estreita relação entre trabalho e saúde, tendo em vista que, segundo Sznelwar, Uchida e Lancman (2011), o simples não reconhecimento do esforço feito pelos sujeitos para produzirem com qualidade, muitas vezes em situações adversas,já seria uma maneira insidiosa de reforçar o registro do sofrimento patogênico. Isso se daria, segundo Dejours (2004), porque na ausência da dinâmica do reconhecimento, o sofrimento não pode ser transformado em prazer, levando-se, assim, o indivíduo a um 
quadro de descompensação psíquica e, por conseguinte, ao adoecimento e patologização da alma (BRANDT e MINAYO-GOMEZ, 2004).

Desta forma, o reconhecimento também se revela como uma das determinantes do sofrimento e adoecimento no ambiente laboral (DEJOURS, 2004), por isso, sua presença se constitui força minimizadora do mal-estar nas organizações, condição para a integridade psíquica do trabalhador, tendo em vista que possibilita a conversão do sofrimento em prazer, o resgate da autonomia e do sentido do trabalho.

Não obstante, em função da ideologia da mais-valia, atualmente dominante no mundo das organizações, a visão do reconhecimento está subordinada à instituição do lucro, "não resulta das qualidades das pessoas, mas de sua capacidade de interiorizar as regras organizacionais, de adaptarem-se às exigências e de reproduzirem a ideologia" (PAGÈS, BONETTI, DE GAULEJA et al., 2006, p. 111). Assim, vencer seria condição para ser reconhecido, admitido e aceito na empresa, ou seja, "no mundo da fantasia e no imaginário dos funcionários, seria o meio de ser amado pela organização" (PAGĖS, BONETTI, DE GAULEJA et al., 2006, p. 134).

Teles (1992, p. 23) destaca ainda outros fatores como determinantes da depressão: decepção no trabalho, estresse,perfeccionismo, medo do fracasso e falta de uma relação plena de confiança e cumplicidade, o que para a mesma autora se daria, porque por detrás da depressão sempre costuma haver um superego bastante severo, entendimento este também compartilhado por Kehl (2009), razão por que as pessoas seriam muito exigentes consigo próprias, daí a presença do sentimento de culpa no deprimido. A presença do sentimento de culpa se constitui, segundo Coser (2003), caminho para o engrandecimento e sentido ético da depressão, já que ela se constitui moeda expiatória para reparação de eventuais danos infligidos pelo depressivo ao objeto de seu amor, constituindo-se, assim, fonte oculta de prazer.

A depressão adviria ainda, segundo Coser (2003), quando da negação do trabalho do luto diante das decepções e da não concretização dos desejos dos indivíduos. Isto se daria, segundo Freud (2011), Peres (2010) e Fédida (2009), porque o luto é condição para a preservação da vida psíquica, e o homem não caminha sem seus lutos,condição para o reconhecimento e aceitação do desaparecimento do objeto amado (desejos), para o enfrentamento do sofrimento e reencontro do sujeito com outros objetivos e sonhos (FREUD, 2011; PERES, 2010).

Desta forma, a ausência do trabalho do luto contribuiria, segundo Fédida (1999, p. 22), para o advento da depressão, bem como do sentimento de culpa, onde "as autoacusações mortíferas se assemelham a um luto interminável, tempo de uma culpabilidade, que representa a atuação persecutória do ausente", ou seja, o desejo não concretizado e ausente constitui-se álibi para a culpabilização do indivíduo, que, absorvido pelo sentimento de incompetência que lhe foi imposto, considera-se o grande culpado pelo fracasso de sua travessia.

Assim, não obstante a importância do trabalho do luto, este se constitui, segundo Coser (2003),um trabalho doloroso, já que demanda o reconhecimento de que o objeto amado não mais está disponível, o que, segundo Fédida (1999, p. 51), "deve levar o eu, no final da rebelião, a aceitar o rigoroso veredito da realidade". Assim, não obstante as agruras do luto, este ocupa papel de relevância no equilíbrio psíquico dos indivíduos, tendo em vista que sua inconclusão ou manutenção dos indivíduos no estado de luto patológico pode ser considerada,segundo Freud (2011), a base da depressão.

Desta forma, não obstante as agruras impostas pela lucidez dos deprimidos (KEHL, 2009), que, segundo Fédida (1999, p. 76), "coloca cada pensamento ou lembrança sob uma iluminação absoluta, onde qualquer sombra é excluída" e a captura de si na rede da escuta e dos olhares faz com que o pensamento sofra por ser cada coisa ouvida, diante do mergulho da alma no mundo das reflexões e da busca de si. A depressão, alimentada por este intenso processo de reflexão, também se revela como o despertar da grande recusa, momento em que o depressivo, em sua estranha recusa, está mais próximo de sua singularidade, autenticidade e fidelidade aos seus desejos (KEHL, 2009). 
Deparamo-nos, assim, com o elogio da depressão, tendo em vista que ela representa a grande recusa, constitui-se sintoma social, sinalizador do mal-estar na civilização, sinal afetivo do perigo e saber das condições contemporâneas do mal-estar, insights que, se bem utilizados,podem contribuir para a reconquista da consciência e do entendimento humano, já que favorecem o processo de autoconhecimento, emancipação, autonomia e capacidade dos trabalhadores de maior intervenção no mundo laboral, gerando-se, assim, melhores condições de saúde e bem-estar no trabalho.

\section{Metodologia}

A pesquisa apresentada neste artigo tem como objetivo identificar vivências depressivas ocorridas no ambiente bancário, bem como seus impactos nas relações de trabalho e na subjetividade dos trabalhadores. Para consecução deste objetivo,foi adotada uma abordagem qualitativa e descritiva, ancorada nos pressupostos teóricos da Sociologia Clínica e da Psicodinâmica do Trabalho.

Referidas correntes teóricas defendem a análise das articulações entre os determinismos sociais e os determinismos psíquicos (GAULEJAC, apud ARAÚJO e CARRETEIRO, 2001). Concentram-se, principalmente, na coletividade do trabalho e não apenas em indivíduos isolados (BOUYER, 2010), além de buscara compreensão dos aspectos psíquicos e subjetivos contidos nas relações de trabalho, ou seja, dos aspectos menos visíveis vivenciados pelos trabalhadores ao longo do processo produtivo, tais como: mecanismo de cooperação, reconhecimento, sofrimento, mobilização da inteligência, vontade, motivação e estratégias defensivas que se desenvolvem e se estabelecem a partir das situações de trabalho. (HELOANI e LANCMAN, 2004).

A utilização destas correntes também seria oportuna, porque amplia o conhecimento dos limites entre normalidade e patologias (BOUYER, 2010), a oferta de espaços que permitam aos trabalhadores o exercício da liberdade de expressão pela fala (benefício da dúvida e do contraditório) e a utilização da inteligência prática, além da possibilidade de negociação das diferentes forças que envolvem o desejo da produção e o desejo do trabalhador (DEJOURS, 1994). Referidos elementos podem prover os homens de melhor compreensão da relação indivíduo-empresa e melhor evidenciação do mal-estar vivenciado pelos trabalhadores em um mundo cada vez mais sob pressão e, por conseguinte, maior capacidade de intervenção dos trabalhadores no mundo do trabalho.

A adoção da abordagem qualitativa e descritiva se dá diante da necessidade de analisar e interpretar aspectos mais profundos de uma população, descrevendo a complexidade do comportamento humano, fornecendo análises mais detalhadas sobre as investigações, hábitos, atitudes e tendências de comportamento. A abordagem qualitativa caracteriza-se, portanto, "como uma tentativa de compreensão mais detalhada dos significados e características situacionais apresentadas pelos entrevistados, em lugar da produção de medidas quantitativas de características ou comportamentos" (LAKATOS, 2006).

Tendo em vista que nossa pesquisa envolveu seres humanos e com o intuito de cumprir as determinações da Resolução 196, de 10 de outubro de 1996, do Conselho Nacional de Saúde, submetemos o projeto à apreciação do Comitê de Ética em Pesquisa - CEP, do Instituto de Ciências Humanas da Universidade de Brasília, onde foi registrado sob o número 12-05/2012, tendo a realização da pesquisa sido aprovada em 20 de junho de 2012.

Para fins de escolha dos bancários entrevistados,recorremos ao serviço de atendimento psicológico do sindicato dos bancários, que, quando do atendimento dos bancários que se enquadravam no público-alvo de nosso trabalho, indagava-lhes de seu interesse em participar da pesquisa e lhes solicitava telefone ou $e$-mail para contato posterior do pesquisador. Foram entrevistados quinze bancários de bancos públicos e privados vítimas de depressão decorrente do trabalho, conforme descrição constante do quadro a seguir: 
Quadro 1

Caracterização do público-alvo da pesquisa

\begin{tabular}{|l|c|l|c|l|}
\hline \multicolumn{1}{|c|}{ Nome } & Idade & Local nascimento & Tempo de Banco & \multicolumn{1}{c|}{ Cargo } \\
\hline Fernanda & 31 & Brasília & 5 & Gerente de contas \\
\hline Pedro & 47 & São Paulo & 20 & Escriturário \\
\hline Vilma & 32 & Brasília & 15 & Gerente de contas \\
\hline Célia & 30 & Brasília & 2 & Caixa \\
\hline Laura & 50 & São Paulo & 30 & Assessora Sênior \\
\hline Ricardo & 42 & Goiás & 20 & Assessor sênior \\
\hline Camilo & 42 & São Paulo & 20 & Assessor sênior \\
\hline Tânia & 55 & Minas Gerais & 25 & Assessora Pleno \\
\hline José & 52 & Rio de Janeiro & 24 & Assessor pleno \\
\hline Antonio & 47 & Rio de Janeiro & 29 & Assistente \\
\hline Marta & 47 & Minas Gerais & 23 & Gerente executivo \\
\hline Joaquim & 31 & Brasília & 10 & Assessor Júnior \\
\hline Paula & 44 & Fortaleza & 4 & Escriturário \\
\hline Clara & 25 & Brasília & Brasília & Escriturário \\
\hline Eva & 29 & Assistente \\
\hline Fonte: & & 42 & \\
\hline
\end{tabular}

Fonte: Dados obtidos a partir das entrevistas realizadas com o público-alvo da pesquisa.

Os entrevistados foram citados neste trabalho com nomes fictícios, trabalham todos em Brasília e têm formações diversas, tanto no nível de graduação (administração de empresas, contabilidade, engenharia florestal, estatística, economia, comunicação, relações públicas e psicologia) como pós-graduação (administração, contabilidade, desenvolvimento regional sustentável, gestão pública, gestão estratégica e gestão de organizações sem fins lucrativos), tendo sido encontrado inclusive um caso de pós-graduação stricto sensu (mestrado).

A idade média dos entrevistados é de 40 anos (intervalo entre de 25 e 55 anos), enquanto que o tempo médio de Banco é de 16 anos (intervalo entre 02 e 30 anos), sendo que a maioria dos entrevistados tem mais de 20 anos de trabalho. Os entrevistados ocuparam diversos cargos dentro das empresas em que trabalham, sendo que à época das entrevistas ocupavam os seguintes cargos: escriturário, caixa, assistente, assessores júnior, pleno e sênior, gerente de contas e gerente executivo.

Para coleta de dados,foi utilizada a técnica da entrevista semiestruturada e semiaberta (LAKATOS, 2006), as quais foram realizadas com base em roteiro de perguntas previamente elaboradas e aplicadas em nível de profundidade, de forma a assegurar a manifestação integral dos entrevistados sobre os temas objeto do 
estudo, viabilizando-se, assim, maior liberdade para o desenvolvimento de questões, manifestação livre de opiniões e sentimentos.

A análise dos dados se deu pela utilização da técnica da análise de conteúdo (AC). Sob à égide das orientações de Bardin (1977), aplicamos a análise categorial, operação de classificação de elementos constitutivos de um conjunto, por diferenciação e, seguidamente, por reagrupamento. Numa primeira etapa,fizemos o inventário das falas (isolamento dos elementos) e, posteriormente, a classificação (repartição dos elementos, organização das mensagens).

Após a etapa de classificação, elegemos para análise, à luz dos pressupostos da Sociologia Clínica e da Psicodinâmica do trabalho, as seguintes categorias e temas, esses últimos entre parênteses: desejo (reconhecimento, proteção e segurança); gestão (individualismo, seleção, governança, desempenho e liderança); alienação (gestão de afeto e do ideal de ego, renúncia, conformismo e demissão do eu); depressão (sofrimento, culpa, vergonha, desamparo e medicalização) e liberdade (resgates: ser, história, desejo, fala e autonomia).. Referidas categorias foram contempladas no roteiro de entrevista aplicado junto aos bancários entrevistados.

\section{Um diálogo entre a depressão e o trabalho bancário.}

O sofrimento e as depressões vivenciadas pelos bancários entrevistados ameaçam sua integridade física e psicológica (DEJOURS, 1994), conforme nos revelam os depoimentos a seguir, o que ratifica a percepção de Castel (2010) e Gaulejac (2007)quando afirmam que a nova organização do trabalho se constituiria fator permanente de insegurança social, canal e instrumento propulsor de adoecimento, máquina de vulnerabilizar, excluir e até mesmo invalidar os trabalhadores:

Arrancaram tudo meu. Aí eu entrei em depressão, naquele dia eu fiquei quinze dias sem dormir. O meu olho ficou todo machucado. Olha, foram oito meses. Eu fiquei muito, mas muito mal. Aí foi a depressão... Na crise eu fiquei oito meses no meu quarto, sem sair. Só para médico, carregada, sem dirigir, fazer cocô, xixi na cama, só andava de modess... Porque não fazia mais nada. Não escovava dente (Laura)

Entrava na agência, dava vontade de rodar naquela portinha e já sair dali na mesma hora. Chorei já lá na agência e, assim, para mim a experiência foi uma das piores. Em casa, não dormia, ficava olhando para o teto, de madrugada ficava com insônia constante. Então assim, a minha qualidade de vida foi a zero (Paula)

A depressão no meio bancário é marcada pela presença de muitas frustrações entre os trabalhadores, com destaque para a ausência e infidelidade aos seus desejos, os quais, segundo Heloani (apud MENDES, 2010), seriam condições para manutenção da saúde mental. Referida visão também é compartilhada por Coser (2003), Teles (1992), Fédida (2009), Kehl (2009) e Birman (2000), autores que enxergam a depressão como o resultado de um despovoamento simbólico, um desinvestimento do mundo exterior, ponto zero do desejo, elementos estes presentes na fala dos bancários, que, desprovidos de confiança em si mesmos, conforme nos revelam os depoimentos a seguir, deixam seus sonhos de carreira dentro e fora do banco desfalecer. Faltamlhes,portanto, entusiasmo e autoestima para renovar seus desejos e reinventar-se, prover-se de uma intencionalidade própria e evitar que a depressão se instale:

Você não tem mais aquele entusiasmo... nem mesmo para estudar outras coisas, o seu incentivo diminui demais, a sua falta de confiança diminui demais ... às vezes até fico querendo fazer outro concurso, mas parece que você não tem tanta confiança própria, sabe? Você se sente desmotivada. Até para fazer outras coisas... É baixa autoestima mesmo, né? A autoconfiança diminui demais (Tânia) 
Então, até uns dois anos, três anos, eu achava que o banco.., eu sonhava em crescer, eu sonhava em fazer carreira. Hoje, eu não sonho mais nada, eu sonho em sair do banco (Vilma).

O desfalecimento dos desejos se revela espaço propício para a exclusão e invalidação dos bancários, que destituídos de autoestima e amor-próprio enxergam na identificação com o outro, "símbolo de sucesso", o resgate do sentido do trabalho. Rendem-se, por isso, à servidão voluntária, patologia social que lhes sequestra a subjetividade e lhes cobra a renúncia de seu próprio eu em prol dos objetivos da organização (GAULEJAC, 2007). Desta forma, segundo Castoriadis (1982), o sujeito não se diz, mas seria dito por alguém (os bancos), conforme exemplo a seguir:

O trabalho me trouxe uma sobrecarga muito grande, uma coisa que eu não percebia. Durante muitos anos eu não percebi isso. Eu sempre fui muito exigida. Eu sempre me permiti ser muito exigida por todas as chefias. E por eu ser uma pessoa muito correta e muito rápida, prática demais, eu fui muito explorada dentro da empresa. Mas sem saber que estava sendo, sem ter essa percepção...Eu ficava sem almoçar, sem ir no banheiro, sem beber água, sem nananan... O meu joelho, eu quebrei correndo para tentar pegar o elevador, saindo de uma reunião para ir para outra. Eu escorreguei, a porta prendeu o meu pé, quando ela abriu, eu desequilibrei e bati a patela assim na quina do granito, quebrou. Eu ainda trabalhei um dia e meio com o joelho quebrado. Dirigindo (Marta).

Assim, seduzidos pelos bancos, os bancários negligenciam o fundamento duplo da vida: amor e trabalho (FREUD, 1974), condição de equilíbrio de qualquer ser humano. Colocam em xeque, conforme nos afirma Pagès, Bonetti, De Gauleja et al. (2006) e Dejours (2004), sua própria integridade psíquica, bem como a sua vida pessoal, afetiva e familiar,conforme visualizamos nos depoimentos a seguir:

Eu viajei muito, o banco me sugou bastante. Para você ter uma ideia, o meu filho foi operado de apendicite, supurado, com 15 anos, eu não estava aqui. A Clara machucou, acidentou duas vezes, de ter que ir para o hospital e tomar ponto, o Artur quase arrancou e (eu estava viajando) (Marta).

Você mal tem tempo de atender um telefonema, você está com criança nova em casa, não tem tempo de parar ali e fazer uma ligação e tal. Você trabalha sem parar...como eu tinha faculdade, eu abri mão totalmente da minha família, eu não tinha tempo para casa, para mais nada. Aí depois eu adoeci, eu parei de render geral. Assim, eu não conseguia mais aprender na faculdade, eu não conseguia mais cuidar da família, eu não conseguia mais... até o relacionamento conjugal, atrapalhou demais (Célia)

A primazia dada ao trabalho em detrimento do fundamento afetivo propugnado por Freud (1974) se deu entre os bancários entrevistados como tentativa de obtenção do reconhecimento dos bancos (DEJOURS, 1994), via encarreiramento, o que também contribuiu para a instituição do sacrifício como dever, na tentativa de assegurar-se a consecução das expectativas organizacionais impregnadas no imaginário dos bancários (GAULEJAC, 2007), as quais, quando não atingidas, impuseram-lhes o sentimento de fracasso e incompetência, bem como o adoecimento do seu corpo e de sua alma (DEJOURS, 2004), conforme nos revela o depoimento a seguir:

Tive a sensação de fracasso total, total, que eu dei um troféu para ela (gerente, grifo nosso) e para o Banco: "olha, vocês venceram, eu sou uma fracassada, eu sou incompetente, eu estou doente, eu não aguentei o rojão, eu não aguentei..." é como se tudo o que você fez 
certo, tudo o que você fez de bom, não valesse nada, o que valesse é aquele momento ruim. Entendeu? (Vilma)

Eu me senti muito mal, por muitos meses, talvez mais de ano, tive uma depressão, um problema muito sério, emocional e comecei a me sentir inferior. Por muito tempo eu me senti totalmente incapaz. (José).

Segundo Enriquez (1997), isto se daria, porque o inconsciente cooptado pelo desejo organizacional não aceita o fracasso, gerando-se, assim, no imaginário dos depressivos um débito a ser honrado no futuro. Referido fenômeno se dá, porque os depressivos,elaborando sobre si um diagnóstico construído sob a égide da menos-valia e de um superego bastante severo,rendem-se ao sentimento de culpa e à depressão como moedas expiatórias (TELES, 1992; GAULEJAC, 2007;PERES, 2010), razão por que, conforme nos revelam os depoimentos a seguir, são muito exigentes consigo próprios em busca do cumprimento dos objetivos e metas estabelecidas pelos bancos:

Eu tenho certeza que eu preciso muito melhorar. Tudo aquilo que eles falaram de mim era verdade (José)

Sentimento de ser incompetente, quando você não bate as metas, de você não... situação de incompetência mesmo, de você ser exposto diante de outras agências, de outros colegas, de achar que você não faz,porque você é fraco. O banco passava isso para a gente: Você não atingiu, porque você é fraco (Fernanda)

Assim, companheiros da depressão e perseguidos pelo fantasma de sua suposta incapacidade, os bancários se renderam ao desencanto absoluto e à falta de esperança no futuro. Para evitar o sofrimento,avocaram o vazio (FÉDIDA, 1999), via morte do desejo e fuga do futuro (demissão do trabalho e aposentadoria), caminhos esses eleitos pelo inconsciente dos bancários como medida de conservação do si em estado de perigo, forma de alimentar no espírito a esperança de gozar novas sensações (FREUD, 1996):

Tentei, mas achei que não estava valendo a pena. Tanto é que,na época, eu encarei tudo sozinha, porque não tinha apoio de ninguém, de ninguém mesmo, para dizer assim: sai. Não tive. Mas o negócio ficou num ponto tão grande que eu disse: não quero isso para mim. ... aí eu preferi a minha qualidade de vida. Pedi demissão sem nenhum emprego (Paula)

A minha pretensão é passar oito anos e me aposentar o mais rápido possível. Não espero mais nada no banco. Eu quero levar o tempo que está faltando, de preferência quietinho no meu canto, não ter que ficar mudando de lugar (Camilo)

Os bancários também nos apresentaram como companheiros da depressão a ausência de amparo e de reconhecimento pelos bancos, elementos esses considerados relevantes por Dejours (1994) para o equilíbrio psíquico dos trabalhadores. Gaulejac (2007) compartilha da mesma percepção, tendo em vista que na sua visão o homem sem trabalho ou não reconhecido em seu trabalho se sente desamparado e está próximo da depressão, chegando comumente a este ponto de ruptura, conforme nos revelaram os depoimentos a seguir:

Eu entrei em depressão, perdi o sono, eu chorava muito, fiquei muito deprimida. Eu não queria sair de casa... Sabe? Aquele tipo assim, desmotivada mesmo, sentimento de desamparo, porque o banco é como se você nunca tivesse trabalhado lá. Não te amparam em nada, te deixam assim, você que se dane, né? (Tânia)

O tempo voa. Eu vou fazer trinta e três anos e é muito ruim você passar anos numa instituição e, quando você adoece, a pessoa não faz nem uma ligação para saber se você 
está bem, ou não. Isso também é um reconhecimento, entendeu? Então, em nenhum aspecto eu sinto o reconhecimento. (Vilma)

Emerge, assim, em função da força do ideal do ego dos bancários, a demanda por reconhecimento, além também de reclamações relacionadas à malversação de sua criatividade e inteligência (DEJOURS, $2004 \mathrm{e}$ GAULEJAC, 2007), elementos que, quando negligenciados, agridem a alma dos bancários em vez de tornarem-se lenitivos de feridas narcísicas que geralmente surgem quando não lhes é ofertado o reconhecimento e, por conseguinte, a possibilidade de exercitar o benefício da dúvida e do contraditório, conforme nos revelaram os depoimentos a seguir:

Eu nunca fui valorizada, eu sempre fui uma mera funcionariazinha barata, sempre para tapar (buracos), resolver problemas (Vilma).

Eles me colocaram para ficar na sala de recepção dos clientes, aí você imagina: funcionário de quatro anos de banco que gostava de atender, de vender e tudo, eu tinha aquela farda para ficar ali no posso ajudar? Muito degradante, eu chorava na hora que chegava em casa, você acha que não deu certo (Joaquim).

Desta forma, sentindo-se não reconhecido pela empresa, já que subaproveitados e não alocados em tarefas adequadas à competência que julgam ter, os bancários perdem sua base narcísica, sua autoestima, seu sentido do trabalho (DEJOURS, 2004). Compromete-se, assim, o contrato narcísico, segundo o qual "o indivíduo espera da empresa que ela favoreça sua realização, enquanto ela espera dele sua adesão incondicional" (GAULEJAC, 2007, p. 229), comportamento esse presente nos discursos a seguir:

O banco não me tem, eu não visto a camisa do banco. Eu estou lá para garantir minha subsistência, não vendo produto nenhum, não faço nada (Clara).

A partir desse momento, eu vi que eu não valia nada para a empresa. Então, como eu não valho nada, a empresa também não vale nada para mim, ela me dá o meu sustento e eu dou o meu trabalho para ela, mais nada. (Camilo).

Os depoimentos acima exemplificam os efeitos da quebra do contrato narcísico assinado "psicologicamente" entre bancários e instituições financeiras. Então, já que as organizações não forneceram o reconhecimento, alimento narcísico esperado pelos trabalhadores, eles desistiram, deixaram morrer o desejo e florescer livremente no seu íntimo a pulsão de morte: tristeza e rancor oriundos dos sentimentos de infidelidade e desamparo a eles impostos por aqueles que no seu imaginário lhes deviam proteção, cuidado e zelo (PAGÈS, BONETTI, DE GAULEJA et al., 2006; GAULEJAC, 2007).

Depararam-se, ainda, os bancários com o desprestígio social de sua tristeza, com o vazio (ausência de desejos) e o culto à exaltação do eu, elemento que impede o reconhecimento, via olhar atento e caridoso para com o outro. Os bancários também se depararam com o isolamento social (GAULEJAC, 2007), a erosão do lugar acordado à subjetividade e à vida no trabalho, além do sentimento de não pertencimento a uma comunidade (DEJOURS e MELLO NETO, 2004), fatores que, segundo Kehl (2009),contribuem para a emergência da depressão, conforme nos revelam os depoimentos a seguir:

Eu fiquei dois anos afastada com depressão, de ficar tomando tarja preta mesmo, de não ver mais sentido na vida... Tive um aborto, estava grávida, e os amigos todos se afastaram de mim. Isolamento é a pior coisa que existe. Eu fiquei isolada dentro do lugar que eu estava trabalhando (Clara). 
Eu fiquei durante muitos meses sem ter nada, nada para fazer. Eu chegava ou eu levava um livro para ler... Não me passavam nada para fazer. Uma coisa assim... me encostaram lá assim para eu não aguentar e sair de lá. Até que um dia o meu chefe disse: Tânia, você não aguenta isso aqui não, você tem que sair daqui, tanto que era assim o isolamento. Ele mesmo fazia, mas a mando do chefe... Aí eu entrei em depressão (Tânia)

Conforme nos revelaram os depoimentos anteriores, o isolamento também se constituiu ferramenta utilizada para penalização dos bancários que, ignorados pelos bancos e pelos seus próprios colegas de trabalho, sentiram-se desamparados, banidos de sua comunidade e desprovidos do sentimento de pertença, conforme nos revelam os depoimentos a seguir:

As pessoas gostavam de mim, mas tinham medo de falar comigo, porque tinham medo de serem prejudicadas, de achar que elas estavam me tratando bem e que iam ser minhas aliadas. Para garantir a comissão delas, garantir o emprego delas tinha que fazer vistas grossas do que estava acontecendo com o colega. Eu acho (Clara)

Ninguém quer conversar comigo, ninguém quer ser visto conversando comigo, porque eu estou queimado com o chefe. Então não tem quem me ouça, isto aí te detona a saúde (Joaquim).

Referido fenômeno se deu,porque, segundo Hirigoyen (2001) e conforme nos revelaram os próprios depoimentos citados anteriormente, os bancários, temendo a antipatia das organizações e, por conseguinte, o risco de seu descarte (FREITAS, 1999), romperam os laços afetivos com os colegas de trabalho considerados como não alinhados aos preceitos e diretrizes organizacionais. Como se não bastasse o rompimento das relações, eles reproduziram e reutilizaram ações e atos dos agressores no ambiente de trabalho, instalando-se, assim, o pacto da tolerância e do silêncio, enquanto a vítima ia gradativamente se desestabilizando, fragilizando-se e perdendo sua autoestima para o assédio moral.

Desta forma, os bancários se auto impuseram a pena do isolamento, conforme nos revelam os depoimentos a seguir, como ferramenta de fuga da dor, da vergonha, da desconfiança e da competição autofágica;esta,reflexo da ética do individualismo, cujo triunfo impõe a ruína do coletivo e da cooperação (DEJOURS e MELLO NETO, 2004) e da cultura da exaltação do eu (BIRMAN, 2000), que se deflagra entre os bancários na busca da concretização de seus desejos de encarreiramento e manutenção no emprego:

Eu não tive apoio nenhum, eu vi que eu não poderia confiar em ninguém. Então, ao mesmo tempo que eu não ia confiar em ninguém, eu não daria nada em troca, eu ia simplesmente cumprir ordens. Eu resolvi me fechar em mim mesmo (Camilo).

Eu nunca tive mais vontade de conviver com as pessoas, solidão total. Eu fiquei quase um ano sem participar de nada da minha família. Você se sente envergonhada, você acha que... é a pior sensação... Não tinha vontade de conviver com as pessoas lá (trabalho, grifo nosso), a minha vontade era de correr para a minha cama. A minha vontade era banco, cama, cama, banco. Não era nem banco, casa, casa, banco. Era banco, cama, cama, banco. (Vilma)

Não obstante a presença da competição e da ameaça do outro (GAULEJAC, 2007), possível sequestrador de desejos, os bancários precisam de dois para melhor compreender a si e a realidade (FÉDIDA, 2009), por isso, faz-se necessário, conforme defende Castoriadis (1982), a elaboração e não a negação do discurso do outro, agente que pode contribuir com o engrandecimento do coletivo e cura da depressão (FÉDIDA, 2009). O depoimento a seguir retrata este movimento, quando nos revela o momento de resgate da fala e do outro, neste caso família, como ferramenta de diálogo e reinserção dos sujeitos na memória coletiva e na 
comunidade a que pertence, enriquecendo-se, assim, a subjetividade e vida psíquica dos bancários, outrora vítima do congelamento da fala pela depressão.

Depois de passar uma tormenta dessa, a gente tenta ficar forte. Mas, graças a Deus, com muito apoio, família... A minha atual esposa, eu comecei a namorar no meio desse furacão aí, uma pessoa muito carinhosa, muito paciente, me ajuda muito também. Então, tendo estrutura familiar, que te dá esse suporte emocional aí, que depois volta e te resgata.... A família ajuda muito. A minha irmã, na época,era solteira também, estava em casa, e nós dois juntos, ela observava isso, dava muito toque em relação a isso: olha, é normal, você vai estar eufórico, triste...E essas oscilações vão diminuindo, como a vida da gente tem momentos mais alegres, mais tristes (Ricardo)

Como forma de evitar a malversação da fala, inteligência prática e criatividade (DEJOURS, 1994), os bancários reivindicam a implementação de políticas e estratégias que contribuam para a semeadura da confiança e a espontaneidade necessária ao livre fluxo da fala e da criatividade, de forma a evitar que aqueles que ousarem aplicá-las sejam tidos como elementos patológicos, espíritos turbulentos e inquietos, a quem caberia penalizações, já que os bancos só enxergavam como bons trabalhadores aqueles que revelaram fidelidade acrítica ao desejo de eficácia: ideal de ego dos bancos (GAULEJAC, 2007):

Insatisfação por não conseguir me fazer ser ouvida. Sabe? De coisas que eu tentei implantar, que eu sabia que seriam coisas boas para a empresa e tal e que, por ego de A, B ou $\mathrm{C}$, porque não foi sua ideia, nem dele, nem dele, foi minha, aí aquilo não foi para frente. Muito provavelmente implantaram nesses dois anos que eu estou fora. Isso me deixou muito insatisfeita com a empresa. (Marta)

Quando eu fui descomissionado, foi bastante traumático assim, porque eu fui descomissionado para dar o exemplo para os outros, né? O diretor lá usou um termo muito pejorativo, porque ele disse que me descomissionou para evitar o risco de contaminação (Pedro)

Isto se daria, porque as organizações negligenciam a complexidade da natureza humana e desprezam ferramentas que a teoria e boas práticas de gestão recomendam aplicação para aproximação das relações instituídas entre superiores e subordinados, a exemplo do feedback. Referida ferramenta, se bem aplicada, forneceria espaço para a escuta e a fala dos trabalhadores, para o trabalho do luto e resolução de conflitos, além do trânsito livre do benefício da dúvida e do contraditório e, por conseguinte,para a revisão das certezas sensíveis hegelianas, para a reformatação de convicções e do próprio entendimento humano.

Assim, diante da ausência do livre fluxo da fala (DEJOURS, 1994) e do trabalho do luto entre os trabalhadores, os bancários encontraram dificuldade em reconhecer e aceitar o desaparecimento de seus objetos de desejo, o que prejudicou a preservação de seu equilíbrio psíquico (FREUD, 2011; PERES, 2010 e FÉDIDA, 2009), por isso Dejours (2004) enxerga no mundo do trabalho um verdadeiro palco de luta contra a loucura.

Seria, portanto, diante desse cenário que emerge a depressão, filha de um trabalho do luto que não avançou e que impôs aos bancários, conforme nos revelaram os depoimentos a seguir, seu aprisionamento na armadilha do rancor, da raiva, da tristeza e do não perdão, dificultando-se, assim, a conquista do autoconhecimento, o enfrentamento do sofrimento e o reencontro dos bancários com outros desejos:

Eu parei de querer contribuir, eu me tornei um cumpridor de ordem. Hoje, não me interesso por mais nada, não dou nenhuma ideia para nada. A falta de apoio da empresa, quando eu precisei, quebrou todo um ciclo de confiança que eu tinha. Eu confiava, eu acreditava. (Camilo) 
Toda corja subiu junto e eu briguei com todos eles. Porque eu sei um monte de coisa errada que eles estavam. ... No frigir dos ovos, a vilã não foi a corja que saiu, que ganhou muita propina, a vilã fui eu (Marta)

Desta forma, diante do cenário em que organizações e os bancários não exercitam o diálogo alteridade, trabalhadores e organizações se confrontam com o risco de interpretar equivocadamente a realidade. Dificulta-se, assim, o resgate da consciência, do desejo, da autonomia, da autoestima, do prazer e da alegria no trabalho, mergulhando-se, portanto, a alma bancária num cenário de sofrimento e depressão, conforme nos revelam os depoimentos a seguir:

Eu comecei a tomar antidepressivos em 2007, tomo até hoje. Eu, com 27 anos, tirei a minha vesícula e a leitura da vesícula e exatamente uma pessoa que guarda muito... engole muito sapo. Hoje eu tomo, porque a dor, o processo de dor, ele deprime a pessoa. E eu venho vivendo um processo de muita dor. No corpo inteiro eu sinto dor. Fibromialgia, eu tenho cinco hérnias, fiz três cirurgias de coluna e operei o ombro, essa cirurgia de ombro ela é terrível, implantou dois parafusos no acrômio, rompeu todos os tendões... Então, assim, eu operei lombar, eu operei a cervical e todo esse processo de dor, ele te deixa mal. Porque tem dia que eu acordo, eu falo: eu não acredito que eu vou ter que levantar, porque dói até a alma (Marta)

Quando comecei a trabalhar no banco, minha vida virou um inferno. Chegava domingo, eu nem conseguia ficar bem, porque eu já ficava: meu Deus, amanhã vai começar tudo de novo. Aí eu comecei a tomar remédio, para conseguir aguentar o dia a dia, a semana, foi aí então que eu cheguei a procurar um psiquiatra, foi porque eu não estava conseguindo mais nem dormir, eu não conseguia dormir pensando nela, pensando naquele ambiente, pensando: meu Deus, mais um dia naquele inferno. Aí eu comecei a ter taquicardia, sabe, o coração muito acelerado. Fiz exame, graças a Deus era superemocional, não tenho nada, mas foi assim um inferno, eu não quero viver isso nunca mais na minha vida. Eu não quero voltar nunca mais. E é ironia, é um clima totalmente hostil... Independente de você bater ou não meta, ser ou não comprometido, você pode fazer tudo certinho, é independente (Vilma).

\section{Considerações finais}

A fala dos trabalhadores entrevistados nos mostrou que os bancários se encontram envoltos por um quadro de precarização das condições do trabalho, que lhes impõe o convívio frequente com o mal-estar e adoecimento psíquico. Consolida-se, assim, a nova organização do trabalho, como fator permanente de insegurança social, instrumento propulsor de adoecimento, máquina de vulnerabilizar, excluir e até mesmo invalidar os trabalhadores bancários, vítimas frequentes de depressão no trabalho.

Os bancários nos revelaram que a depressão se apresenta entre eles perante um cenário dominado pela ética do individualismo, do espírito da competição, da cultura do narcisismo e exaltação do eu. Referidos fatores contribuíram para que os trabalhadores bancários, presos às armadilhas de seus próprios desejos (encarreiramento e manutenção no emprego), deflagrassem a crise da solidariedade do coletivo do trabalho e a destruição das relações de confiança frente à insurgente sociedade do espetáculo, ferramenta de exaltação do eu que alardeia qualidades, realizações profissionais e números produzidos, de forma a assegurar a visibilidade individual e afugentar o receio de que o outro se aproprie dos seus desejos mais particulares, mesmo que para isso tenham que algumas vezes, ainda que de forma tácita, esconder o brilho daqueles que ameaçam chegar primeiro ao trono do desejo. 
Assim, diante de um cenário que coloca entre parênteses as relações alteritárias, elege o exibicionismo como essência da existência e deflagra entre os trabalhadores uma luta renhida pela conquista de visibilidade e não raramente, até pelo ostracismo do outro (ameaça mortal para a existência autocentrada do individualismo), não é de surpreender que os bancários se defrontem frequentemente com ausência do reconhecimento, tanto de seus pares, como da própria organização do trabalho, o que contribui para a emergência da depressão,já que o homem sem trabalho ou não reconhecido em seu trabalho chega comumente a este ponto de ruptura, conforme nos revelaram os depoimentos dos bancários entrevistados.

Não obstante a força da ética do individualismo e da sociedade do espetáculo, os bancários precisam lutar contra o culto à exaltação do eu, que impede o olhar atento e caridoso necessário para o reconhecimento do outro, bem como contra o isolamento social imposto aos trabalhadores, de forma a resgatar o prestígio social de sua tristeza e o sentimento de pertencimento a uma comunidade, por meio de sua inclusão na corrente da memória coletiva. Faz-se necessário, também, resgatar o respeito ao discurso do outro, o que beneficiará o livre fluxo da fala, da dúvida, do contraditório e, portanto, o enriquecimento da subjetividade e vida psíquica dos bancários, vítimas do congelamento da fala pela depressão.

O isolamento social se revelou, ainda, ferramenta utilizada pelos bancos para penalização dos bancários tidos como não alinhados com os objetivos e metas organizacionais,razão por que eles também se depararam com o rompimento dos laços afetivos e a rejeição do convívio social de seus próprios colegas de trabalho, os quais temiam herdar a antipatia das organizações, logo, o descarte de seu corpo de funcionários. Referido fato contribuiu significativamente para sequestro da autoestima dos bancários pelo assédio moral.

Assim, atemorizados pelo fantasma da menos-valia, os bancários, vítimas da competição autofágica, que se deflagra entre eles, em busca da concretização dos objetivos organizacionais (metas e resultado financeiro) e, por conseguinte, de seus desejos de encarreiramento e manutenção no emprego, convertem a solidão em desejo, ferramenta de fuga da desconfiança, da dor e da vergonha que se abate sobre sua alma diante da não consecução dos objetivos organizacionais.

Os bancários entrevistados também apresentaram como práticas desencadeadoras do sofrimento e depressão no trabalho o cerceamento da fala, da criatividade e inteligência prática. Referidos elementos, quando presentes, contribuem para a conquista do autoconhecimento,maior autonomia (domínio do consciente sobre o inconsciente), espírito coletivo (confiança, generosidade e solidariedade social) e fluxo livre do diálogo (fala e escuta), além da conquista do direito à curiosidade epistemológica (problematização da realidade, benefício da dúvida e do contraditório).

Desta forma, diante do cenário em que organizações e bancários não exercitam o diálogo alteridade, trabalhadores e organizações se confrontam com o risco de interpretar equivocadamente a realidade. Dificulta-se, assim, o resgate da consciência, do desejo, da autonomia, da autoestima, do prazer e da alegria no trabalho, o que mergulha a alma bancária num cenário de sofrimento e depressão. Isso se dá, porque as organizações negligenciam a complexidade da natureza humana e desprezam ferramentas que a teoria e as boas práticas de gestão recomendam para aproximação das relações instituídas entre superiores e subordinados.

Uma dessas principais ferramentas citadas pelos bancários foi o feedback, ferramenta que viabiliza o espaço dialógico reservado à escuta e fala dos trabalhadores, ao trabalho do luto, ao benefício da dúvida e do contraditório, elementos que favorecem a resolução de conflitos e a revisão das certezas sensíveis hegelianas (convicções ingênuas). Esses movimentos viabilizarão, portanto, a reformatação de convicções e do próprio entendimento humano, processo este que deve acontecer sem que os trabalhadores que exercitam a arte do questionamento dialético sejam vistos como espíritos turbulentos e inquietos, a quem caberiam penalizações. Infelizmente, referido risco é iminente, tendo em vista que os bancos só enxergavam como bons trabalhadores aqueles que revelaram fidelidade acrítica ao seu próprio ideal de ego (desejo das organizações). 
Os bancários nos revelaram também que a depressão é fecundada diante da presença de frustrações, entre as quais destacaram a infidelidade ou demissão de seus próprios desejos em prol dos objetivos das organizações, os quais se revelaram instrumentos de exclusão e invalidação de sujeitos, que, destituídos de autoestima e amor-próprio, enxergaram na identificação com os bancos a esperança de sucesso e de resgate do sentido do trabalho, razão porque se renderam à servidão voluntária, patologia social que lhes sequestrou a subjetividade, via renúncia do seu próprio eu.

Desta forma, envoltos pelo ideário organizacional, os bancários negligenciam o fundamento duplo da vida (amor e trabalho) em prol dos desejos dos banqueiros. Assim, abdicando de sua vida pessoal, afetiva e familiar,colocaram em xeque sua própria integridade psíquica, tudo isto na tentativa de fugir do tabu do fracasso, receio de não atender às expectativas dos bancos, o que, quando aconteceu, gerou entre os depressivos um sentimento de fracasso e incompetência, além de um débito a ser honrado no futuro, o que se deu porque os depressivos, elaborando sobre si um diagnóstico construído sob a égide da menos-valia e de um superego bastante severo, utilizaram-se da depressão como moeda expiatória.

Companheiros da depressão e perseguidos pelo fantasma de sua suposta incompetência, os bancários se renderam ao desencanto absoluto e à falta de esperança no futuro. Assim, para evitar o sofrimento, avocaram o vazio, via morte do desejo e fuga do futuro (pedidos de demissão do trabalho e aposentadoria). Os caminhos citados foram eleitos pelo inconsciente dos bancários como medida de conservação do si em estado de perigo, forma de alimentar no espírito a esperança de gozar novas sensações.

Referido fenômeno não se mostrou presente entre todos os bancários entrevistados, já que alguns, não vivenciando adequadamente o trabalho do luto, encontraram dificuldade em reconhecer e aceitar o desaparecimento de seus objetos de desejo, o que prejudicou a preservação do equilíbrio psíquico dos bancários e possibilitou a fecundação da depressão, filha de um trabalho do luto que não avançou. Impõe-se, assim, aos bancários o seu aprisionamento na armadilha do rancor, da raiva, da tristeza e do não perdão, sentimentos esses filhos da depressão.

Não obstante, referidos sentimentos dificultarem o enfrentamento do sofrimento e a renovação do desejo, a depressão oferece aos bancários deprimidos insights sinalizadores das condições contemporâneas do malestar no trabalho. Cônscios dessa realidade, os bancários se deparam com um descontentamento interior que lhes dá força para deflagrar a grande recusa às tentativas de alienação da subjetividade dos trabalhadores, elemento importante no processo de emancipação e autonomia dos trabalhadores bancários.

Os bancários vítimas da depressão passaram, então, a cobrar o tão necessário repensar das práticas de gestão e das relações estabelecidas entre eles e os bancos, de forma a deflagrar-se um conjunto de ações transformadoras deste cenário. Entre referidas ações, destacam-se as seguintes: resgate da sociedade do ser, renovação da confiança e da solidariedade, reconquista dos desejos e da possibilidade de questionamento de certezas sensíveis e ingênuas. Enfim, resgate da autonomia dos bancários, forte aliada da dimensão política dos trabalhadores, elemento esse também necessário para recusa da banalização de práticas de gestão hostis à dignidade do espírito dos trabalhadores.

Para o resgate da sociedade do ser, os bancários e as organizações deverão apropriar-se de novos princípios que assegurem a centralidade do papel do trabalhador no universo corporativo, bem como o resgate da solidariedade e do espaço do social sequestrado pelo econômico sem, contudo, negligenciar a importância do diálogo entre os termos econômicos e sociais, bem como entre os interesses individuais e coletivos, os quais, quando em conflito, devem ser intermediados por um bom processo de governança.

A governança atuaria na gestão dos conflitos de interesses, limitando a concentração do poder, instituindo a pluralidade de centros de decisão, bem como regras de convivência e ascensão profissional nas organizações, de forma a inibir o florescimento da sociedade do espetáculo, patrocinadora do exibicionismo, da naturalização da luta por lugares e do darwinismo organizacional. 
A governança também proporcionaria às organizações e aos seus trabalhadores todas as possibilidades ofertadas pela democracia: autonomia, benefício da dúvida e do contraditório, ordem, segurança, equidade e transparência, elementos esses que se revelam condição sine qua non para o exercício da dimensão política dos trabalhadores. Tais elementos também se mostram relevantes para a religação de causas e efeitos e adequada leitura da realidade, via ruptura esclarecida com ilusões e desejos. Descortina-se, assim, a possibilidade de reforma da consciência e do entendimento humano, bem como da instituição de uma gestão mais humana dos trabalhadores, marcada por uma economia associada às demandas da sociedade, não refém exclusivamente do econômico, onde o indivíduo-recurso (homem-utensílio) é substituído pelo indivíduosujeito.

\section{REFERÊNCIAS}

ABRAHÃO, J. I.; TORRES, C. C. Entre a organização do trabalho e o sofrimento: o papel de mediação da atividade. Revista Produção, v. 14, n. 3, p. 67-76, Dez. 2004.

ANTUNES, R. Adeus ao trabalho?: Ensaio sobre as metamorfoses e a centralidade do mundo do trabalho. 15. ed. São Paulo: Editora Cortez, 2011.

ARAÚJo, J. N. G.; CARRETEIRO, T. C. Cenários sociais e uma abordagem clínica. São Paulo: Editora Escuta, 2001.

BARDIN, L. Análise de conteúdo. Lisboa: Edições 70, LDA, 1977.

BIRMAN, J. Mal-estar na atualidade. Rio de Janeiro: Civilização Brasileira, 2000.

BOUYER, G. C. Contribuição da Psicodinâmica do Trabalho para o debate: "o mundo contemporâneo do trabalho e a saúde mental do trabalhador". Revista brasileira de saúde ocupacional, v. 35, n. 122, p. 249-259, Dez. 2010.

BRANDT, L. C.; MINAYO-GOMEZ, C. A Transformação do Sofrimento em Adoecimento: do nascimento da clínica à Psicodinâmica do Trabalho. Ciência e Saúde Coletiva, Rio de Janeiro, v. 9, n. 1, p. 213-223, 2004.

BRASIL. Ministério da Previdência Social. Informações estatísticas sobre segurança e saúde ocupacional. Disponível em: <http://www.previdencia.gov.br/estatisticas/menu-de-apoio-estatisticas-seguranca-e-saude-ocupacionaltabelas>. Acesso em: 13 de set. 2012

CASTEL, R. As metamorfoses da questão social: Uma crônica do salário. Tradução: Iraci D. Poletti. 9.Ed. Petropólis, RJ: Vozes, 2010.

CASTELlS, M. A Sociedade em Rede: A era da informação: Economia, Sociedade e Cultura. Tradução: Roneide Venancio Majer. 6. ed. São Paulo: Paz e Terra, 1999.

CASTORIADIS, C.A instituição imaginária da sociedade. Tradução de Guy Reynaud. 5. ed. Rio de Janeiro: Paz e Terra, 1982.

Uma sociedade à deriva: entrevistas e debates - 1974 -1997. Tradução: Enrique Escobar, Myrto Gondicas e Pascal Vernay. Aparecida, São Paulo: Ideias e Letras, 2006.

COSER, O. Depressão: clínica, crítica e ética. Rio de Janeiro: Editora FioCruz, 2003.

DEJOURS, C. Subjetividade, trabalho e ação. Revista Produção, v. 14, n. 3, p. 27-34, Dez. 2004.

Da psicopatologia à psicodinâmica do trabalho. Tradução Franck Soudant. Organizadores: Selma Lancman e Laerte Idal Sznelwar. Rio de Janeiro: Fiocruz, 2004. 
Vargas, 2007.

A Banalização da injustiça social. Tradução: Luiz Alberto Monjardim. Rio de Janeiro: Fundação Getulio

; ABDOUCHELI, E.; JAYET, C. Psicodinâmica do trabalho: Contribuições da Escola Dejouriana à análise da relação prazer, sofrimento e trabalho. Tradução: Maria Irene Stocco Betiol et al. São Paulo: Editora Atlas, 1994.

; MELlO NETO, G. A. Ramos Psicodinâmica do trabalho e teoria da sedução. Revista Psicol. estud., v.17, n. 3, p. 363-371, Set. 2012.

DEL PORTO, J. A. Depressão, conceito e diagnóstico. Revista Brasileira de Psiquiatria, São Paulo, v. 21, n. S.1, p.611, maio 1999.

ENRIQUEZ, E. A Organização em Análise. Tradução: Francisco da Rocha Filho. Petrópolis, RJ: Vozes, 1997.

O homem do século XXI: Sujeito autônomo ou indivíduo descartável. RAE Eletrônica, v. 5, n. 1, artigo 10, Janeiro/Junho 2006.

FÉDIDA, P. Depressão. Tradução Martha Gambini. São Paulo: Escuta 1999.

Dos benefícios da depressão: elogio da psicoterapia. Tradução Martha Gambini. São Paulo: Escuta 2009.

FERREIRA, M. C.; SEIDL, J. Mal-estar no trabalho: análise da cultura organizacional de um contexto bancário brasileiro. Psicologia, teoria e pesquisa, v. 25, n. 2, p. 245-254, Jun. 2009.

FREITAS, M. E. Cultura Organizacional: Identidade, Sedução e Carisma? Rio de Janeiro: Fundação Getulio Vargas, 1999.

FREUD, S. O futuro de uma ilusão, o mal-estar na civilização e outros trabalhos. Tradução: José Octávio de Aguiar Abreu. v. XXI. Rio de Janeiro: Imago Editora Ltda., 1974.

Inibições, sintomas e angústia. Tradução: José Octávio de Aguiar Abreu. v. XX. Rio de Janeiro: Imago Editora Ltda., 1996.

Luto e Melancolia. Tradução: Marilene Carone. São Paulo: Cosac Naify, 2011.

GAUlEJAC, V. As origens da Vergonha. Tradução Maria Beatriz de Medina. São Paulo: Editora Via Lettera, 2006.

Gestão como doença social: Ideologia, poder gerencialista e fragmentação social. Tradução: Ivo Storniolo. São Paulo: Idéias\& letras, 2007.

Travail, lês raison de lacolère. Paris: Seuil, 2011.

GRISCI, C. L. I. Dos corpos em rede às máquinas em rede: reestruturação do trabalho bancário e constituição do sujeito. Revista de Administração Contemporânea, v. 7, n. 1, p. 87-108, 2003.

. et al. Nomadismo involuntário na reestruturação produtiva do trabalho bancário. Revista de Administração de Empresas, v. 46, n. 1, p. 27-40, 2006.

HELOANI, R.; LANCMAN, S. Psicodinâmica do trabalho: o método clínico de intervenção e investigação. Revista Produção, v. 14, n. 3, p. 77-86, Dez. 2004.

HIRIGOYEN, M. Assédio Moral: a violência perversa no cotidiano. Tradução Rejane Janowitzer. 2. ed. Rio de Janeiro: Bertrand Brasil, 2001.

JINKINGS, N. O mister de fazer dinheiro: Automatização e subjetividade no trabalho bancário. São Paulo: Editores Associados, 1995. 
KEHL, M. R. O tempo e o cão: a atualidade das depressões. São Paulo: Boitempo, 2009.

LAKATOS, E. M.; MARCONI, M. A. Metodologia Científica: Ciência e conhecimento; métodos científicos; teoria, hipóteses e variáveis; metodologia jurídica. São Paulo: Editora Atlas, 2006.

MARCUSE, H. A Ideologia da Sociedade Industrial. Tradução: Giasone Rebuá. Rio de Janeiro: Editora Zahar, 1967.

MENDES, A. M. et al. (Org.). Violência no trabalho: perspectivas da Psicodinâmica, da Ergonomia e da Sociologia Clínica. São Paulo: Universidade Presbiteriana Mackenzie, 2010a.

et al. (Org.). Psicodinâmica e Clínica do Trabalho: Temas, interfaces e casos brasileiros. Curitiba: Editora Juruá, 2010b.

MERLO, Á. R. C. Suicídios na France Telecom: As consequências nefastas de um modelo de gestão sobre a saúde mental dos trabalhadores. Universidade Federal do Rio Grande do Sul - Pró-reitoria de Gestão de Pessoas - 2009. Disponível em: <http://www.ufrgs.br/progesp/progesp-1/setores/dima/arquivos/estagio-probatorio/dossier\%20 suicidio \% 20na\%20France\% 20 Tele con \%20Prof\%20Alvaro.pdf >. Acesso em: 13 fev.2012.

PAGÈS, M. et al. O poder das organizações. Tradução: Maria Cecília Pereira Tavares e Sonia Simas Favatti. São Paulo: Atlas, 2006.

PAZ, R. France Telecom: 24 suicídios em 18 meses. Sapo. Pt, 2009. Disponível na internet em <http://economico.sapo.pt/noticias/france-telecom-24-suicidios-em-18-meses_70792.html>. Acesso em: 13 fev.2012.

PERES, U. T. Depressão e Melancolia. 3. ed. Rio de Janeiro: Zahar, 2010.

SANTOS, M. A. F. Tentativas de suicídio de Bancários no contexto das reestruturações produtivas. Revista de Administração Contemporânea - RAC, Curitiba, v. 14, n. 5, p. 925-938, Set./Out. 2010.

SENNET, R. A corrosão do caráter: consequências pessoais do trabalho no novo capitalismo. Tradução: Marcus Santarrita. 11. ed. Rio de Janeiro: Record, 2006.

SILVA, L. S.; BARRETO, S. M. Stressful working conditions and poor self-rated health among financial services employees. Revista Saúde Pública, v. 46, n. 3, p. 407-416, 2012.

SIQUEIRA, É. S. Earp. A depressão e o desejo na psicanálise. Estudos e Pesquisas em Psicologia, Rio de Janeiro, v. 7, n.1, p.71-80, Jun. 2007.

SZNELWAR, L. I.; UCHIDA, S.; LANCMAN, S. A subjetividade no trabalho em questão. Tempo soc., v. 23, n. 1, p. 11-30, 2011.

TEIXEIRA, S. A depressão no meio ambiente do trabalho e sua caracterização como doença do trabalho. Revista Tribunal Regional do Trabalho, $3^{\text {a }}$ Região, Belo Horizonte, v. 46, n. 76, p. 27-44, Jul./Dez. 2007.

TELES, M. L. S.O que é depressão. São Paulo: editora brasiliense, 1992. 